\title{
Effect of Organisational Factors on Employee Turnover Intention: An Empirical Study of Academic Professionals at Jordanian Government Universities
}

\author{
Abdullah Abbas Al-khrabsheh (Corresponding author) \\ Prince Al-Hussein bin Abdullah II Academy of Civil Protection, Al-balqa Applied \\ University, Jordan \\ E-mail: abdbbs@gmail.com \\ Maisoon Abo-Murad \\ Prince Al-Hussein bin Abdullah II Academy of Civil Protection, Al-balqa Applied \\ University, Jordan \\ E-mail: maisoonabomurad@yahoo.com
}

\section{Islam Bourini}

Business Administration Department, College of Business Administration, Al Falah University, Dubai, UAE

E-mail: Islam.bourini@afu.ac.ae

Received: March 19, 2018 Accepted: April 12, 2018 Online published: April 16, 2018

doi:10.5296/ijhrs.v8i2.12847ＵRL: https://doi.org/10.5296/ijhrs.v8i2.12847

\begin{abstract}
This study aims to examine the relationship between turnover intention and some organisational factors among professional academics at Jordanian Government Universities. Namely the organisational factors include job satisfaction, work exhaustion, occupational health and safety management and organisational culture. A sample of 250 participants was extracted from different Jordanian universities. The participants were limited to academics in Jordan who are working in any government Jordanian University. Statistical analysis was conducted by using SPSS 23. Previous literature was also used to design a structured questionnaire. A total of 250 questionnaires were given out and 250 questionnaires were
\end{abstract}


collected back. The study then conducted correlation and regression analysis to determine the relationship between the independent and the dependent variables. The models for multiple regression offer support for the relationship between turnover intention and organizational factors. The results revealed that the all the exogenous variables had a significant effect on the endogenous variable. Based on these results, the study implies that managers need to acknowledge the importance of examining the factors that reduce the turnover intentions of the employees and improve the commitment level for their employees.

Keywords: job satisfaction, turnover intention, work exhaustion, organization culture, occupational health and safety management

\section{Introduction}

Alzubi (2018) gathered alarming evidence regarding Jordanian academic situation. During the last 25 years, approximately 3000 academics in Jordan left their job. Over the past eight years, twenty percent of Jordanian academics wanted to look for opportunities in other universities, most of which were located abroad. It is expected for this particular percentage to rise to more than $60 \%$ towards the end of 2020 . Even though low turnover rates can be advantageous because they provide fresh opportunities for new talents and ideas, high rates can be disruptive and have a negative effect on the image of Jordan's academic sector.

The turnover of employees has always been an Important concern for organisations, regardless of their sizes, locations, business strategy (profit or non-profit oriented), or natures of business. Yin-Fah et al. (2010) also stated that the turnover of employees is a major concern, especially in terms of managing human resources. Furthermore, Ali (2009) stated that if the turnover issue of employees is not solved, there will be an increase in the organizational cost expenditure. Studies were also conducted both globally and regionally to examine the relationship that employee turnover has with various variable(s).

According to Salahudin et al. (2009), the rate of employee turnover ranges from 3 to 27\% within Small Medium Enterprises (SMEs). This is based on the World Bank report regarding to the current situation in developing countries. SMEs operating in Malaysia, which is a developing country, were able to record one of the highest turnover numbers, which are $19 \%$ and $22 \%$ for small enterprises and medium-sized enterprises, respectively.

Employee's turnover is often expensive for all of the organisation's levels, regardless of its nature. Furthermore, it always negatively affects the productivity and quality of the organisation's products or services. Ali (2009) further stated that high employee turnover greatly affects both direct and indirect costs, which could damage organisations. Direct costs refer to costs like the expenses incurred during the recruitment, selection, training, and induction of new employees (Staw, 1980). On the other hand, indirect costs refer to the cost of reduced morale, learning, and pressure on the current employees (Dess and Shaw, 2001). Moreover, high rates of employee turnover can harm the organisation's progress towards achieving its pre-determined goals and objectives. Other than measurable monetary costs, non-monetary costs such as damaged reputations, loss of customer loyalty, degraded trust in the brand which all may lead to more serious long-term effects (Dess and Shaw, 2001). 
According to Zacharatos, Barling, \& Iverson (2005), workers assume that their organisations will take all the necessary safety measures to make sure that at the end of the work day, they will be able to go home safe. Nevertheless, work-related injuries and deaths still take place at alarming rates. Every year, over 250 million work-related accidents are reported.

\section{Literature Review}

\subsection{Turnover Intention}

One can define turnover intention as the personal estimated probability of an employee that he or she deliberately intends to permanently leave the organisation in the near future. Employee turnover intention refers to an employee who is thinking of quitting his/her job (Firth et al., 2004). The term "intention" serves as the main determinant of the act of quitting from the job behaviour (Salahudin et al., 2009).

One can classify and categorise turnover into voluntary or involuntary. It can also be classified as either functional or dysfunctional. Each of these classifications will affect the organization at varying degrees (Wells and Peachey, 2010). According to Wells and Peachey (2010), one can define voluntary turnover as a process where the employee makes a decision on whether he/she will stay or leave the organisation. Mobley (1982) states that this is usually a dysfunctional turnover and can be the most damaging to the organisation. Mobley (1992) also warned that the employees who are most likely to choose to leave the organisation are the smartest and most talented employees in the group. As a result, their valuable experiences, skills, talents, and knowledge will leave with them and lead to decreased efficiency (Abbasi and Hollman, 2000).

\subsection{Job Satisfaction}

Lund (2003) defines job satisfaction as a perceived relationship between what an individual wants from his/her job and what that individual perceives the job offers him (Lund, 2003). Jones and George (2004) state that job satisfaction is the collection of the employees' feelings and beliefs about their jobs. Job satisfaction also refers to the general attitude that employees have towards their job (Rezaiean et al., 2010). It is a vital concern for every employer as it has been stated that a satisfied employees will have a greater likelihood of showing up for work, have higher performance levels, and stay with an organisation (Robbins et al., 2010). Additionally, job satisfaction has also been defined as one's positive attitude towards his or her assigned jobs or tasks (Daft, 2010).

During the last 40 years, job satisfaction has been extensively examined by researchers and theorists from different organisations, professions and industries (Currivan, 1999 and Lund, 2003). Theorists and researchers around the world have been trying to determine and examine the different factors and theories related to job satisfaction. This includes that the examination of the relationship between job satisfaction and organisational variables like cohesion, performance, organisational commitment, industries, age and gender, and organisational environment (Lund, 2003).

Theorists like Bryman (1992), Herzberg (1966), and Maslow (1954) studied and developed 
theories that are related to job satisfaction. For example, the hierarchy of needs theory developed by Maslow proposes that multiple needs in hierarchical order are what motivate people. In order to satisfy higher-order needs, the lower-order needs need to be fulfilled first. These needs are ordered as follows - physiological needs, safety needs, belongingness needs, esteem needs and self-actualisation needs (Daft, 2010).

Herzberg's two-factor theory (hygiene and motivator factors) is another popular motivation theory. This theory suggests that the work characteristics or behaviour that is associated with dissatisfaction differ from those that are associated to satisfaction. Herzberg stated that the two separate dimensions that contribute the behaviour of the employee during work are motivator and hygiene factors. Hygiene factor describes factors that are outside the job, such as salary, working conditions, security, supervision, and company policies. On the other hand, motivator factors are factors like opportunities for achievement, responsibility, recognition, challenge on the job, and personal growth. Some of these factors are intrinsic to the actual work (Dessler and Starke, 2004). When there are no motivator factors, workers will remain neutral towards work. However, when motivator factors are present, workers become satisfied and highly motivated. According to Herzberg, the best way to give employees motivation is to construct opportunities and challenges for job achievement, i.e. offering intrinsic motivation (Akinyele, 2007)

\subsection{Work Exhaustion}

According to the argument presented by Moore (2010), work exhaustion is claimed to have extensive relevance to all kinds of jobs. The definition of work exhaustion as given by Moore is: "the depletion of mental and emotional energy that is required to meet the demands of a job". Hence, emotional exhaustion is an integral part of work exhaustion. In the study conducted by Schaufeli W, Leiter M, Kalimo R. (1995), a wide diversity of nurses was sampled, and it was argued that work exhaustion was a more suitable measure for exhaustion. Several researchers have emphasised that emotional or work exhaustion is the primary reason for experiencing burnout, and is also the key factor in triggering the burnout process. As mentioned by Lee \& Ashforth (1996), work exhaustion must be considered and analysed as a "stand alone" effect. An empirical relationship has been found between work exhaustion and higher job turnover target vested on information technology professionals. According to Moore (2000) and the meta-analysis of Lee and Ashforth, emotional exhaustion is found to have a substantial relation with high turnover intention.

On the contrary, involuntary turnover refers to the condition where the organisation takes on the control over the employee's choice to leave or stay in the organisation (McPherson, 1976). Because of the frequent elimination of under-performing employees in an organisation, this is classified as functional turnover (Watrous et al., 2006)

\subsection{Organisational Culture}

The major transformations in the functional and management processes of organisations, institutions, and companies have resulted in high competition and requisites. Hence, this has led to the formation of a new "culture" in the structure of general effort that helps to sustain 
the organisations' internal completion and external modification (Schein, 1991). Besides this general culture that typifies the industry or fields, services and sales, the various research results show that the general function of the organisation and the behaviour of the employees are influenced by three types of culture: national, organisational and occupational (Hofstede, 1991). A culture that is specific to the organisation is an outcome of occupational relations among employees, relations between employees and managers, and relations between employees and customers. Therefore, the culture is not constant and is likely to adapt and reform to the institution's or organisation's strategies and goals.

An organisational culture is an unstable entity that is influenced by individual attitudes, preferences, and characteristics, and is generally an accepted situation. Earlier studies have validated the occurrence of differences between the preferred and dominant type of organisational culture in various working fields, for example, Koustelios (1996) collected the views of employees from three types of organisations: a) public sector, b) public organisations and enterprises (public electricity enterprise and banks), and c) private sector. The Employee Satisfaction Inventory, ESI, designed by Koustelios (1991), was used for measuring employee job satisfaction, while a 15-variable questionnaire was used for measuring the organisational culture, where each variable had four options - types of organisational culture. The outcome of the exercise divulged that the current culture in most fields was very different from the desired culture.

\subsection{Occupational Health and Safety Management}

Diseases and work-related injuries are a serious problem and highly concern for every country and pose a substantial challenge to unions, managers, governments and specifically the workers themselves. As rightfully mentioned by Steenkamp and Van Schoor (2002), occupational health and safety management is a complicated problem that is internationally relevant for the organisational management and the society, and therefore it needs to be considered as a top priority. Disasters do not have nationalities or borders, and negligible mistakes can have significant impacts. Consequently, this is why nations should come together and promote occupational health, and safety actively and extensively to attain the common goal of fast warning, protection and prevention of health hazards for all (Barling and Hutchinson, 2000). The responsibility to offer a healthy and safe work environment for employees has long been with the management and the company or organisation as a whole. However, the implementation of health and safety measures that are meant to protect employees from hazards in the workplace can often contradict the objective of limiting production cost (Yankson E, 2012). Workers should function in a healthy and secure environment; this would enable them to give their best for achieving the organisational objectives. Thus, it is important to maintain safety and wellbeing at the place of work as it has a significant effect on the reputation of a firm. It is advantageous to employees and their representative to earn a living, and reach old age in healthy circumstances (World Health Organization, 2007). This is not conflicting but complementary to the business' interest. Secure and healthy working conditions are in the interest of employers, employees, governments and the general public. Even though it appears easy and clear, this idea has not yet attained significant universal appreciation. Millions of people worldwide work in 
conditions which are unhealthy and/or unsafe.

\subsection{Relationship between Job Satisfaction and Turnover Intention}

Many research works have been conducted for scrutinising the relationship between job contentment and turnover intention (Yin-Fah et al., 2010; Ryan et al., 2010; Park and Kim, 2009; Ali, 2009; Amah, 2009). A study carried out by Yin-Fah et al. (2010) on private sector personnel in Petaling, Selangor (Malaysia) with the objective to analyse the job pressure, organisational commitments, job contentment and turnover intention demonstrated a conflicting or negative association between job contentment and turnover intention.

Ryan et al. (2010) carried out a study for scrutinising the deciding aspects behind the intent to quit a job held by non-managerial employees in the fast food industry of Malaysia. This includes problems like job pressure and peer groups. The results indicate that $20 \%$ of the samples often think of quitting the job. Another $20 \%$ were observed to be committed and stuck with their employment. Furthermore, the high intent to quit was driven by the influence of friends, job pressure and burn-out. According to Ryan et al., (2010) Job pressure and the burn-out feeling certainly affect job contentment of employees. Park and Kim (2009) conducted a study for ascertaining the relationship between organisational culture, turnover intention and job contentment among Korean hospital nurses.

\subsection{Relationship between Job Occupational Health and Safety Management and Turnover Intention}

The mining sector is termed as one of the most risky and perilous sectors. The need for effectual and useful occupational health and safety management is vital for protecting employees and the industry. In spite of the risks and hazards existing in the mining sector, only few research works have emphasised on how occupational health,safety and turnover intentions are related in this sector (Zacharatos , Barling, \& Iverson, 2005). Employees, just like humans in emerging nations, presume that their organisations will take all the essential precautions to make sure that they return home safely after their day at work ends. Still, injuries and fatalities at the work place continue to happen at a disturbing rate. Every year, over 250 million work-related mishaps occur.

\subsection{Relationship between Organisational Culture and Turnover Intention}

Meyer et al. (2002) studied the relationship between employee commitment and organisational culture and intention to stay at an energy firm in Canada. According to the authors, employee devotion and intention to stay would be more when there is an organisational culture likeness between the ones that employees perceive and the favoured organisational culture. They evaluated pre-change worker dedication and intention to stay one month prior to business reorganisation. Paper surveys were handed out to the entire labour force, and 699 (67\%) came up with a response. Seven months following the restructuring, the researchers evaluated post-change worker commitment and intention to stay through another paper survey handed over to the entire labour force, of whom 637 (59\%) replied. The researchers employed response surface analysis and polynomial regression for every dependent variable (commitment and intention to stay) for ascertaining the employee 
alignment with organisational culture. They noted that organisational culture had a correlation with intent to stay (lower turnover intention). The organisational culture likeness had a positive relation with employee commitment and intention to stay.

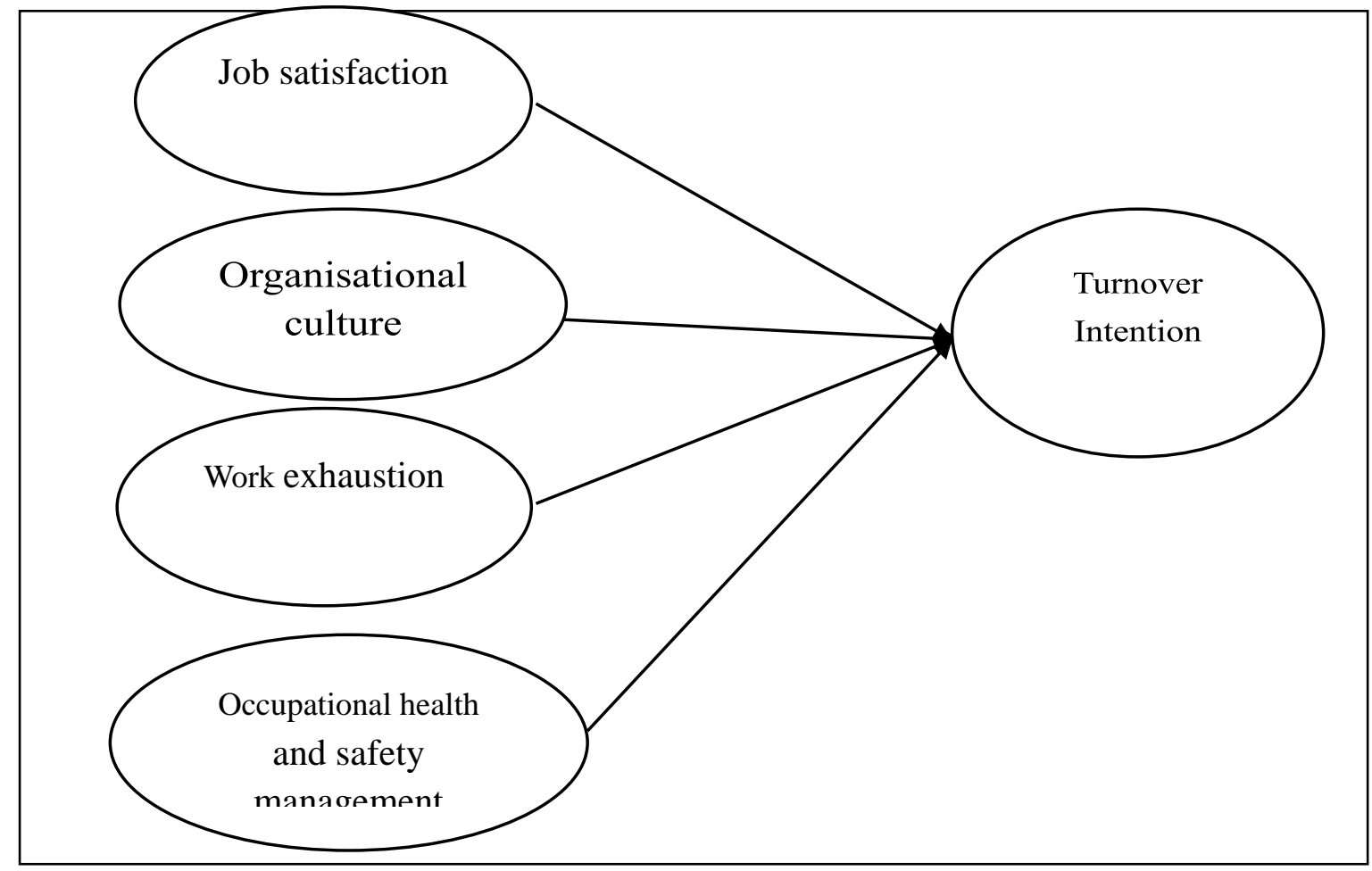

Figure 1. Theoretical framework

One of the hypotheses tested was "job satisfaction will be negatively associated with turnover intention". This hypothesis was accepted (i.e. job satisfaction has a negative relation with turnover intention when it comes to nurses in Korea).

Ali (2009) carried out a study on the factors impacting the overall job contentment and turnover intention of academic employees or lecturers in a private college in Pakistan. The researcher noted that overall job contentment was observed to have a significant negative relationship with turnover intention.

Amah (2009) carried out a survey on the moderating impact of life satisfaction and job role centrality on the relationship between turnover intention and job contentment in a new-generation bank headquartered in Lagos, Nigeria and having branches across the nation. The researcher contends that the new-generation banks are extremely automated with aggressive marketing programs and plans. Furthermore, these banks recruit personnel with different academic qualifications. The banks offer very good salaries as well as significant autonomy so as to retain them. The survey, which covered 1200 participants out of the 5000-strong employee head count, indicated the presence of a negative relationship between turnover intention and job contentment, in line with the majority of research works stated above.

Research propositions and theoretical structure: This study intends to investigate the 
relationship between job contentment and turnover intention as depicted in the abstract model (Fig. 1). Thus, the propositions state the following:

- Proposition 1: Occupational health and safety management would have a positive relation with turnover intention.

- Proposition 2: Job satisfaction would have a positive relation with turnover intention.

- Proposition 3: Organisational culture will be positively related to turnover intention.

- Proposition 4: Work exhaustion will be positively related to turnover intention.

\section{Methodology}

The study employed a descriptive survey design. As per Ezeani (1998), the objective of descriptive surveys is to gather exhaustive and factual data which outlines a prevailing phenomenon. The study deploys the quantitative methodology that enables the relationship between the variables to be ascertained through statistical techniques. This is in line with the goal of the current study, i.e. to scrutinise the relationship between turnover intention organisational factors. It also permits the scrutiny to be conducted on a large scale; this can be generalised to the entire populace. Furthermore, it enables utilisation of formal and standard questionnaire sets.

\subsection{Instrumentation}

Occupational health and safety management Farrell and Rusbult (1992) Lapidus and Waite's [X] 28-item occupational health and safety management scale were utilised to gauge the facets of occupational health and safety management viewpoints. The scale comprised four facets which are empirically discrete from each other: facilities/equipment, safety leadership, supervision, and safety management program process. Responses were recorded on a 5-point Likert Scale ranging from 1 (strongly disagree) to 5 (strongly agree). Higher scores represent higher perceptions of the degree of occupational health and safety management present at work, whereas lower scores represent perceptions of less safe workplace environments.

\subsubsection{Turnover Intention}

Based on Farrell D, Rusbult (1992), a turnover intention scale with 6 items was utilised to measure the plans of respondents to leave or else stay with their organisation. Each respondent rated 6 statements along a Likert scale of 5 points that ranged from 5 (strongly agree) to 1 (strongly disagree). Higher scores signified potentially higher intentions to leave (turnover), while lower scores implied a lower likelihood of staff turnover intention.

\subsubsection{Job Satisfaction}

This study applied the "General Index of Job Satisfaction" device of Brayfield and Rothe (1951), as translated into the Greek and revised by Kafetsios and Loumakou (2007). A set of 12 items were utilised for rating along a Likert scale of 5 points that ranged from 5 (strongly agree) to 1 (strongly disagree). 


\subsubsection{Organisational Cultures}

This section comprises measurements of cultural dimensions, with the aim of examining the essential characters and bases of cultures in terms of rational and hierarchical types. The 10 -item set was adopted from the work of Yang (2005).

\subsubsection{Work Exhaustion}

Work-based exhaustion was assessed with a 5-item measure from Gillespie and Numerof Scale (Gillespie and Numerof, 1991). Prior studies have utilised such adaptations effectively (Blau et al., 2003; Blau and Ward-Cook, 2006). Physical-based exhaustion was assessed using 4-item scale recognised by the FSMTB and applied in prior studies (Blau, 2009; Blau et al., 2009).

\subsection{Research Analysis}

\subsubsection{Descriptive Analysis}

Table 1. The demographic characteristics of the participants in the study

\begin{tabular}{lcc}
\hline Variables & $\mathrm{N}$ & $\%$ \\
\hline Sex & & \\
Female & 168 & 67.2 \\
Male & 82 & 32.68 \\
\hline Marital State & & \\
Single & 88 & 35.2 \\
Married & 162 & 64.8 \\
\hline Age & & \\
$23-32$ & 179 & 71.6 \\
$33-42$ & 48 & 19.2 \\
$>43$ & 23 & 9.2 \\
\hline Work Experience & & \\
$1-7$ & 119 & 47.6 \\
$8-14$ & 79 & 31.6 \\
$15-21$ & 54 & 20.8 \\
\hline Education & & \\
PhD & 179 & 71.6 \\
Master & 48 & 19.2 \\
bachelor & 23 & 9.2 \\
\hline
\end{tabular}

Based on the findings in Table 1, the majority of participants were female (67.2\%) and of ages ranging from 23 to 32 years old $(71.6 \%)$, with work experiences 1 to 7 years $(47.6 \%)$. The majority of 179 had Doctorate degrees (71.6\%).

Table 2. Means, Standard deviations, Correlations between major variables in the study.

\begin{tabular}{|c|c|c|c|c|c|c|}
\hline Variable & Mean & Std. & 1 & 2 & 3 & 4 \\
\hline $\begin{array}{c}\text { Occupational } \\
\text { health and safety } \\
\text { management }\end{array}$ & 3.13 & 59.0 & 1 & & & \\
\hline Job satisfaction & 3.11 & 43.0 & $0.15 * *$ & 1 & & \\
\hline $\begin{array}{c}\text { Organizational } \\
\text { culture }\end{array}$ & 3.24 & 77.0 & $0.14 *-$ & $0.15 *$ & 1 & \\
\hline $\begin{array}{c}\text { Work } \\
\text { exhaustion }\end{array}$ & 3.24 & 60.0 & $0.41 * *$ & $0.49 * *$ & $0.60 * *$ & 1 \\
\hline $\begin{array}{l}\text { Turnover } \\
\text { intention }\end{array}$ & 3.12 & 0.50 & $0.44 * *$ & $0.25 * *$ & $0.40 * *$ & $0.20 * *$ \\
\hline
\end{tabular}




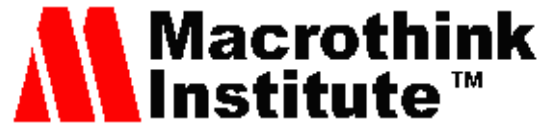

*. Correlation is significant at the 0.05 level (2-tailed). **. Correlation is significant at the 0.01 level (2-tailed).

The association between organisational factors and turnover intentions was evaluated using Pearson correlational analysis. Table 2 depicts the overall findings of inter-correlations among variables which are statistically significant at $p<.05$ and the $95 \%$ confidence level. Strongest positive correlations were found in the association of job satisfaction with turnover intentions. Pearson correlational analysis signified $\mathrm{r}=0.15$ and $\mathrm{P}=0.000$ with significance at the 0.01 level (2-tailed). The secondary correlational association of significance among organisational culture contracts and turnover intentions signified at $\mathrm{r}=.60$ and $\mathrm{P}=000$. Strong correlation was determined in the work exhaustion contract association with staff turnover intention, signified at $\mathrm{r}=-.241, \mathrm{P}=0.000$, at the 0.01 level (2-tailed). The study's hypotheses were therefore supported.

Table 3. Results of Regression

\begin{tabular}{c|c|c|c|c}
\hline Variable & B & T & Beta & Sig \\
\hline Occupational health and safety management & .325 & 5.397 & .000 & .249 \\
\hline Job satisfaction & .259 & 8.913 & .000 & .258 \\
\hline Organizational culture & .189 & 6.956 & .000 & .185 \\
\hline Work exhaustion & .301 & 8.234 & .000 & .356 \\
\hline (DV) Turnover intention & \multicolumn{5}{|l}{} \\
\hline
\end{tabular}

Table 3 depicts the findings of multiple regression analyses on the independent variable and the dependent variable. The findings demonstrate that of the 5 items in the independent variable set, the 4 comprising occupational health and safety management, Job satisfaction, organisational culture, and workplace exhaustion are significantly related to turnover intentions.

\section{Conclusion}

This study was performed using surveys of professional scholars at Jordanian Government Universities. The general aim was to investigate the influences of organisational factors, job satisfaction, work exhaustion, organisational culture and occupational health and safety management on turnover intentions. With the 4 variables and the inter-relationship model examined, results show that the independent variable set significantly influences the dependent variable. The research implications are that managers who work at Jordanian universities must recognise the significance of research factors that motivate staff to be committed to their organisation, so as to reduce staff turnover intentions.

This study is considered as one of the new research area that links occupational health and safety management with turnover intention. Further research is needed in the future to investigate in depth the impact of occupational health and safety management on turnover intention in different sectors. 


\section{References}

Abbasi, S. M., \& Hollman, K. W. (2000). Turnover: The real bottom line. public Personnel management, 29(3), 333-342. https://doi.org/10.1177/009102600002900303

Akinyele, S. T. (2007). Needs satisfaction: An effective tool for workers commitment to $\begin{array}{llll}\text { work. Research Journal of } \quad \text { Business } & \text { Management, 1(1), }\end{array}$ https://doi.org/10.3923/rjbm.2007.72.79

Ali, N. (2008). Factors affecting overall job satisfaction and turnover intention. Journal of Managerial Sciences, 2(2), 239-252.

Alzubi, Y. Z. W. (2018). Turnover intentions in Jordanian Universities: The role of leadership behaviour, organizational commitment and organizational culture. International Journal of Advanced and Applied Sciences, 5(1), 177-192. https://doi.org/10.21833/ijaas.2018.01.024

Amah, O. E. (2009). Job Satisfaction and Turnover Intention Relationship: The Moderating Effect of Job Role Centrality and Life Satisfaction. Research \& Practice in Human Resource Management, 17(1).

Bakker, A. B., Schaufeli, W. B., Sixma, H. J., Bosveld, W., \& Van Dierendonck, D. (2000). Patient demands, lack of reciprocity, and burnout: A five-year longitudinal study among general practitioners. Journal of Organizational Behavior, 425-441. https://doi.org/10.1002/(SICI)1099-1379(200006)21:4<425::AID-JOB21>3.0.CO;2-\#

Barling, J., \& Hutchinson, I. (2000). Commitment vs. Control-based Safety Practices, Safety Réputation, and Perceived Safety Climate. Canadian Journal of Administrative Sciences/Revue Canadienne Des Sciences De L'administration, 17(1), 76-84. https://doi.org/10.1111/j.1936-4490.2000.tb00208.x

Blau, G. (2009). Can a four-dimensional model of occupational commitment help to explain intent to leave one's occupation?. Career Development International, 14(2), 116-132. https://doi.org/10.1108/13620430910950737

Blau, G., Pred, R. S., Daymont, T., Hochner, A., Koziara, K., Portwood, J., ... \& Tatum, D. S. (2009). Exploring relationships to three types of occupation perceptions: forced to stay in occupation, voluntary occupation withdrawal intent, and involuntary occupation withdrawal. Journal of allied health, 38(1), 31-38.

Blau, G., Surges, T. D., \& Ward-Cook, K. (2003). Correlates of work exhaustion for medical technologists. Journal of Allied Health, 32(3), 148-157.

Blau, G., Yang, Y., \& Ward-Cook, K. (2006). Testing a measure of cyberloafing. Journal of Allied Health, 35(1), 9-17.

Brayfield, A. H., \& Rothe, H. F. (1951). An index of job satisfaction. Journal of applied psychology, 35(5), 307. https://doi.org/10.1037/h0055617

Bryman, A. (1992). Charisma and leadership in organizations. Sage Pubns. 


\section{Macrothink}

International Journal of Human Resource Studies

ISSN 2162-3058

2018, Vol. 8, No. 2

Cordes, C. L., \& Dougherty, T. W. (1993). A review and an integration of research on job burnout. Academy of management review, 18(4), 621-656.

Currivan, D. B. (1999). The causal order of job satisfaction and organizational commitment in models of employee turnover. Human resource management review, 9(4), 495-524. https://doi.org/10.1016/S1053-4822(99)00031-5

Dess, G. G., \& Shaw, J. D. (2001). Voluntary turnover, social capital, and organizational performance. Academy of management review, 26(3), 446-456.

Dessler, G., \& Starke, F. A. (2004). Management: principles and practices for tomorrow's leaders. Pearson/Prentice Hall.

Draft, R. L. (2008). New era of management. Thompson Corporation, USA.

Ezeani, S. I. (1998). Research methods: A realistic approach. Ibadan: Elohim Publishers.

Farrell, D., \& Rusbult, C. E. (1992). Exploring the exit, voice, loyalty, and neglect typology: The influence of job satisfaction, quality of alternatives, and investment size. Employee Responsibilities and Rights Journal, 5(3), 201-218. https://doi.org/10.1007/BF01385048

Firth, L., Mellor, D. J., Moore, K. A., \& Loquet, C. (2004). How can managers reduce employee intention to quit?. Journal of managerial psychology, 19(2), 170-187. https://doi.org/10.1108/02683940410526127

Gillespie, D. F., \& Numerof, R. E. (1991). Burnout among health service providers. Administration and Policy in Mental Health and Mental Health Services Research, 18(3), 161-171. https://doi.org/10.1007/BF00713800

Herzberg, F., (1966). Work and Nature of Man. Cleveland The World Publishing Company, Ohio.

Hofstede, G. (1991). Organizations and cultures: Software of the mind. McGrawHill, New York.

Jones, G. R., \& George, J. M. (2004). Essentials of Contemporary Management. McGraw Hill Companies, Inc., Boston.

Kafetsios, K., \& Loumakou, M. (2007). A comparative evaluation of the effects of trait emotional intelligence and emotion regulation on affect at work and job satisfaction. International Journal of Work Organisation and Emotion,2(1), 71-87. https://doi.org/10.1504/IJWOE.2007.013616

Koustelios, A. (1991). The relationships between organizational cultures and job satisfaction in three selected industries in Greece. University of Manchester.

Lee, R. T., \& Ashforth, B. E. (1996). A meta-analytic examination of the correlates of the three dimensions of job burnout. Journal of applied Psychology,81(2), 123. https://doi.org/10.1037/0021-9010.81.2.123

Lund, D. B. (2003). Organizational culture and job satisfaction. Journal of business \& 
industrial marketing, 18(3), 219-236. https://doi.org/10.1108/0885862031047313

Maslow, A. H. (1954). Motivation and Personality Harper \& Row New York Google Scholar.

McPherson, B. D. (1976). Involuntary turnover and organizational effectiveness in the National Hockey League. Canadian sport: Sociological perspectives, 259-275.

Meyer, J. P., Stanley, D. J., Herscovitch, L., \& Topolnytsky, L. (2002). Affective, continuance, and normative commitment to the organization: A meta-analysis of antecedents, correlates, and consequences. Journal of vocational behavior, 61(1), 20-52. https://doi.org/10.1006/jvbe.2001.1842

Mobley, W. H. (1982). Employee turnover: Causes, consequences, and control. Addison-Wesley.

Mobley, W. H. (1992). Turnover: causas, consequências e controle. Ortiz.

Moore, J. E. (2000). One road to turnover: An examination of work exhaustion in technology professionals. Mis Quarterly, 141-168. https://doi.org/10.2307/3250982

Moore, J. E. (2000). Why is this happening? A causal attribution approach to work exhaustion consequences. Academy of Management Review, 25(2), 335-349.

Rezaiean, A., Givi, M. E., Givi, H. E., \& Nasrabadi, M. B. (2010). The relationship between organizational justice and organizational citizenship behaviors: the mediating role of organizational commitment, satisfaction and trust. Research Journal of Business Management, 4(2), 112-120. https://doi.org/10.3923/rjbm.2010.112.120

Robbins, S. P., Decenzo, D. A., \& Coulter, M. (2010). Fundamentals of Management: Essential Concepts and Applications. 7th Edn., Prentice Hall, New Jersey, ISBN: 9780136109822, Pages: 450.

Ryan, C., Ghazali, H., \& Mohsin, A. (2011). Determinants of intention to leave a non-managerial job in the fast-food industry of West Malaysia. International Journal of $\begin{array}{lll}\text { Contemporary Hospitality } \quad \text { Management, 23(3), } & \text { 344-360. }\end{array}$ https://doi.org/10.1108/09596111111122523

Salahudin, S. N., Baharin, N. L., Abdullah, M. M., Harun, M. Z. M., \& Taufek, F. H. M. (2009). Occupational content and turnover intention: A case study of small and medium sized enterprises. In Proceedings of International Conference on Human Capital Development (Vol. 31, No. 2, pp. 63-73).

San, P. J., \& Hyun, K. T. (2009). Do types of organizational culture matter in nurse job satisfaction and turnover intention?. Leadership in Health Services, 22(1), 20-38. https://doi.org/10.1108/17511870910928001

Schaufeli, W. B., Leiter, M. P., \& Kalimo, R. (1995, September). The General Burnout Inventory: A self-report questionnaire to assess burnout at the workplace. In Work, Stress and Health (Vol. 95, pp. 14-16). 
Schein, E. H. (1991). What is culture. Newbury Park, CA: Sage Publicatios, 243-253.

Staw, B. M. (1980). The consequences of turnover. Journal of occupational Behaviour, 253-273.

Steenkamp, R., \& Van Schoor, A. J. (2002). The quest for quality of work life: A TQM approach. Juta and Company Ltd.

Walumbwa, F. O., Wang, P., Lawler, J. J., \& Shi, K. (2004). The role of collective efficacy in the relations between transformational leadership and work outcomes. Journal of Occupational and Organizational Psychology, 77(4), 515-530. https://doi.org/10.1348/0963179042596441

Watrous, K. M., Huffman, A. H., \& Pritchard, R. D. (2006). When coworkers and managers quit: The effects of turnover and shared values on performance. Journal of Business and Psychology, 21(1), 103-126. https://doi.org/10.1007/s10869-005-9021-2

Wells, J. E., \& Welty, P. J. (2011). Turnover intentions: do leadership behaviors and satisfaction with the leader matter?.Team Performance Management: An International Journal, 17(1/2), 23-40. https://doi.org/10.1108/13527591111114693

Wharton, A. S. (1993). The affective consequences of service work: Managing emotions on the job. Work and 205-232. https://doi.org/10.1177/0730888493020002004

Yang, J. (2005). The relationships of the organizational culture, commitment to change, and to behavioral support for organizational change in Taiwan (Doctoral dissertation, Nova Southeastern University).

Yankson, E. (2012). The effect of health and safety standards on productivity in Ghana rubber estates limited (Doctoral dissertation).

Yin-Fah, B. C., Foon, Y. S., Chee-Leong, L., \& Osman, S. (2010). An exploratory study on turnover intention among private sector employees. International Journal of Business and Management, 5(8), 57.

Zacharatos, A., Barling, J., \& Iverson, R. D. (2005). High-performance work systems and $\begin{array}{llll}\text { occupational safety. Journal of applied psychology,90(1), } & 77 .\end{array}$ https://doi.org/10.1037/0021-9010.90.1.77

\section{Copyright Disclaimer}

Copyright for this article is retained by the author(s), with first publication rights granted to the journal.

This is an open-access article distributed under the terms and conditions of the Creative Commons Attribution license (http://creativecommons.org/licenses/by/4.0/). 